\title{
Epithelial cell response to challenge of bacterial lipoteichoic acids and lipopolysaccharides in vitro
}

\author{
M. T. PÖLLÄNEN, J . I. SALONEN*, D. GRENIER† and V.-J . UITTO† \\ Institute of Dentistry, University of Turku, Finland, *Kuwait University, Faculty of Dentistry, Safat, Kuwait, \\ $\dagger$ Universite Laval, Quebec and $¥$ University of British Columbia, Vancouver, Canada
}

\begin{abstract}
Accumulating dental plaque at the gingival margin contains lipoteichoic acids (LTAs) from the cell walls of gram-positive bacteria. In subgingival plaque associated with periodontal disease the amount of lipopolysaccharides (LPSs) from gram-negative bacteria increases. As the gingival junctional epithelium (JE) is an important structural and functional tissue, participating in the first line defence against apical advancement of dental plaque, this study examined the direct effects of LTAs (from Streptococcus mutans and S. sanguis) and LPSs (from Actinobacillus actinomycetemcomitans, Porphyromonas gingivalis, Treponema denticola and Escherichia coli) on two epithelial cell lines ( $\mathrm{HaCaT}$ and ERM ) and a culture model for human JE. The cells were exposed to the LTAs or LPSs $(10-50 \mu \mathrm{g} / \mathrm{ml})$ for variable periods of time. None of the bacterial surface components had any effect on primary adhesion or on the epithelial attachment of the JE cultures. However, cell growth and mitotic activity were consistently reduced in all cultures treated with LTAs. In contrast, LPSs showed only slight or no effects on cell growth and mitotic activity depending on the epithelial cells used. This suggests that LPSs, despite their established role as modulators of inflammation, do not have direct harmful effects - at the concentrations found in dental plaque and gingival crevicular fluid - which would explain the mechanism of epithelial degeneration and detachment from the tooth surface. However, the LTAs appear to inhibit the renewal of epithelium and may thus contribute to degeneration of coronal JE and subgingival colonisation by periodontal pathogens.
\end{abstract}

\section{Introduction}

Gingival junctional epithelium (JE) is a rapidly renewing tissue with proliferating basal cells along the connective tissue and a distinct population of proliferating cells attached to the tooth surface (DAT cells) [1]. The suprabasal location of these dividing epithelial cells is unique and appears to render them vulnerable to exogenous influences. Therefore, it seems pertinent to examine the effects that oral bacterial agents may have on epithelial cell growth and mitotic activity. Cessation of division and subsequent degeneration and detachment of the DAT cells would inevitably affect the JE barrier and expose tooth surface to apically progressing pathogenic micro-organisms. A number of metabolic end-products and structural components of

Received 8 March 1999; revised version accepted 13 Aug. 1999.

Corresponding author: $\operatorname{Dr}$ M. T. Pöllänen (e-mail: marja. pollanen@utu.fi). bacteria have been associated with periodontal diseases $[2,3]$. For example, elevated concentrations of shortchain fatty acid (SCFA) metabolites of gram-negative bacteria have been reported in plaque and gingival crevicular fluid (GCF) collected from sites exhibiting gingival inflammation $[4,5]$. Interestingly, SCFAs significantly reduce epithelial cell growth and proliferation in vitro at concentrations reported in plaque and GCF $[6,7]$. Also, lipoteichoic acids (LTAs) from the surface of gram-positive bacteria and lipopolysaccharides (LPSs) from gram-negative bacteria have been associated with periodontal diseases [8-12]. It has been suggested that LTAs and LPSs mediate bacterial adherence to the tooth surface and to epithelial cells [13-15]. Furthermore, bacterial surface antigens have been reported to increase epithelial permeability, penetrate healthy gingival sulcular epithelium [16, 17], cause complement activation, stimulate leucocyte function and increase cytokine production and bone resorption [10,18-24]. In addition, different LPSs show a slight enhancement of gingival fibroblast proliferation at concentrations below $1 \mu \mathrm{g} / \mathrm{ml}$, modest 
to significant suppression of fibroblast proliferation at a concentration range of $10-200 \mu \mathrm{g} / \mathrm{ml} \mathrm{[25-29]} \mathrm{and}$ degeneration and death of fibroblasts at concentrations of $300-500 \mu \mathrm{g} / \mathrm{ml}[28,30]$. B oth growth enhancement and growth inhibition have been described in rat epithelial cells after treatment with LPS from non-oral bacteria [31-34]. Despite the presence of both LTAs and LPSS in dental plaque in the immediate environment of the dividing JE cells [9, 12, 35-36], information on the effects of oral bacterial LPSs and LTAs on epithelial and especially on JE cells is lacking. Furthermore, as the structure of the LPSs and LTAS varies between bacterial species and also between strains $[37,38]$, this study investigated the effects of LTAS and LPSS of selected oral microbial species associated with different clinical conditions on epithelial culture systems commonly used in periodontal research.

\section{M aterials and methods}

\section{Cell cultures}

A spontaneously transformed non-tumorigenic human skin epithelial cell line that has maintained epithelial differentiation properties ( $\mathrm{HaCaT})$ [39] and an epithelial cell line cultured from porcine epithelial rests of Malassez (ERM) [40] were used for this study. The cells were grown in plastic tissue-culture flasks (Nunc) in Dulbecco's modification of Eagle's medium (DMEM, Gibco) containing $22 \mathrm{mM}$ sodium bicarbonate, $20 \mathrm{~mm}$ HEPES, antibiotics (penicillin G $100 \mathrm{IU} / \mathrm{ml}$, streptomycin sulphate $100 \mu \mathrm{g} / \mathrm{ml}$, amphotericin B $0.25 \mu \mathrm{g} / \mathrm{ml}$ ) and heat-inactivated fetal calf serum (FCS) $10 \%$. The cells were trypsinised (trypsin $0.5 \%$-EDTA in HBSS, pH 7.2, Gibco) and divided into appropriate aliquots of cells for studies on cell adhesion, growth and proliferation.

\section{Primary tissue culture}

Masticatory mucosa was obtained, with informed consent, from four subjects undergoing a surgical exposure of impacted teeth for orthodontic reasons. The tissue was prepared and cultured to mimic JE as described previously [41]. B riefly, the tissue was cut perpendicularly to the epithelium surface into elongated fragments of c. $1 \times 1 \times 2 \mathrm{~mm}$. The fragments were then placed on their sides on Millipore filters (pore size $0.45 \mu \mathrm{m}$ ) supported by a grid and cultured in a Petri dish in Eagle's minimum essential medium (EMEM, Gibco) with Earle's balanced salts solution containing $2 \mathrm{~mm}$ L-glutamine, $10 \mathrm{~mm}$ sodium bicarbonate, antibiotics (penicillin G $100 \mathrm{IU} / \mathrm{ml}$, streptomycin sulphate $100 \mu \mathrm{g} / \mathrm{ml}$, amphotericin B $0.25 \mu \mathrm{g} / \mathrm{ml}$ ), $20 \mathrm{~mm}$ HEPES and heat-inactivated FCS $10 \%$. Tissue explants were cultured for 6 days before the experiments on cell proliferation, morphology and the epithelial attachment apparatus (EAA); during this period the medium was changed every other day.

\section{Bacterial LPSs and LTAs}

LPSs from Actinobacillus actinomycetemcomitans (strain Y 4), Treponema denticola (ATCC 35405) and Porphyromonas gingivalis (ATCC 33211, W 83) were purified as described previously [42]. LPS from Escherichia coli (055:B5, L-2880) and LTAs of Streptococcus mutans (L-4152) and S. sanguis ( $L$ 3765) were purchased from Sigma. LPSs were added into the culture medium at a concentration of $50 \mu \mathrm{g} /$ $\mathrm{ml}, \mathrm{LTAs}$ at a concentration range of $10-50 \mu \mathrm{g} / \mathrm{ml}$. The direct effects of LPSs and LTAs from different bacterial species on epithelial cells were compared to find out whether they caused different cellular responses.

\section{Cell adhesion}

For the studies of cell adhesion, epithelial cells ( $\mathrm{HaC}$ aT and ERM) were seeded into microtitration plates (96well plates, Nunc) $2 \times 10^{4}$ cells/well in DMEM + FCS $10 \%$ in four parallel wells. LTA s or LPSs were added at the time of starting the culture and their effects were studied after incubation for 2,4 or $6 \mathrm{~h}$ at $37^{\circ} \mathrm{C}$. A fter incubation, the medium and non-adhered cells were discarded and the adhered cells were fixed overnight in formaldehyde $4 \%$ in PBS containing sucrose $5 \%$, washed four times with distilled water and air-dried. The cell numbers were determined after staining with crystal violet $0.1 \%$ in boric acid $(200 \mathrm{~mm}, \mathrm{pH} 6.0)$ at room temperature for $30 \mathrm{~min}[43,44]$. The dye bound to the cells was dissolved in equal amounts of acetic acid $10 \%$ and the absorbances were read with a Multiscan M s Primary EIA reader with a 595-nm filter.

\section{Cell growth}

For the assessment of cell growth, epithelial cells ( $\mathrm{HaCaT}, \mathrm{ERM}$ ) were seeded into 96-well plates (Nunc) at $1 \times 10^{4}$ cells/well in $200 \mu \mathrm{l}$ of DMEM containing FCS $10 \%$ and allowed to attach for $18 \mathrm{~h}$ in four parallel wells. M edium and unattached cells were discarded and replaced with $200 \mu \mathrm{l}$ of medium containing LTA or LPS at a concentration range of $10-50 \mu \mathrm{g} / \mathrm{ml}$. Cells were incubated at $37^{\circ} \mathrm{C}$ in $\mathrm{CO}_{2} 5 \%$ in air for 7 days. During the incubation the medium was changed to new medium containing LTA or LPS every other day. A fter the culture period, the cells were fixed and stained and the number of cells in each well was determined by crystal violet staining as described above.

\section{Cell proliferation}

For studies of the direct effects of the LTAs and LPSs on epithelial cell proliferation, $\mathrm{HaCaT}$ and ERM cells were seeded $\left(3 \times 10^{4}\right.$ cells/well $)$ on two parallel coverslips into a 24-well plate in $1 \mathrm{ml}$ of DMEM containing FCS $10 \%$. Cells were cultured at $37^{\circ} \mathrm{C}$ in $\mathrm{CO}_{2} 5 \%$ in air for 2 days, then the LPSs or LTAs ( $50 \mu \mathrm{g} / \mathrm{ml}$ ) were added. After 2 more days in culture, 
the cells were treated with $10 \mu \mathrm{M}$ 5-bromo-2'-deoxyuridine-5'-monophosphate (BrdU; Sigma) for 2 ( $\mathrm{HaCaT}$ ) or 12 (ERM) h. The assay was performed according to the manufacturer's instructions for the BrdU Labelling and Detection Kit (B oehringer M annheim Biochemica). B riefly, the cells were fixed in ethanol $70 \%$ (in $50 \mathrm{~mm}$ glycine buffer, $\mathrm{pH}$ 2) for $30 \mathrm{~min}$ at $-20^{\circ} \mathrm{C}$ and then incubated with mouse monoclonal antibody to $\mathrm{BrdU}$ containing nucleases for DNA denaturation for $30 \mathrm{~min}$ at $37^{\circ} \mathrm{C}$. Fluorescein-conjugated anti-mouse immunoglobulin was used to identify the cells that had incorporated BrdU. Between each antibody incubation the cells were washed twice with PBS diluted with distilled water (1 in 10). The cells on the coverslips were attached on to microscope slides for examination. Four randomly selected fields of each treatment were photographed with an A ristoplan research microscope equipped with UV illumination and the ratio of labelled to non-labelled cells was counted.

A tissue-culture model for JE was used for the study of human epithelial cell proliferation in primary cultures. After 6 days in culture in EMEM, the explants were randomly placed in fresh medium without (control, $n=8$ ) or containing LTA (S. sanguis, $n=6 ; S$. mutans, $\mathrm{n}=6) 50 \mu \mathrm{g} / \mathrm{ml}$ or LPS (T. denticola, $\mathrm{n}=$ 3; A. actinomycetemcomitans, $n=8$; $E$. coli, $n=3$; $P$. gingivalis, $\mathrm{n}=10) 50 \mu \mathrm{g} / \mathrm{ml}$ and cultured for a further 2 days. To examine the DNA synthesis by the epithelial cells under each culture condition, the explants were placed for $3 \mathrm{~h}$ in a medium to which ${ }^{3} \mathrm{H}$-thymidine (specific activity $37 \mathrm{MBq}, 1 \mathrm{mCi} / \mathrm{ml}$ ) $5 \mu \mathrm{l} / \mathrm{ml}$ was added. The explants were then rinsed with fresh medium for $30 \mathrm{~min}$, fixed in glutaraldehyde $5 \%$ in $0.16 \mathrm{M}$ collidine- $\mathrm{HCl}$ buffer ( $\mathrm{pH}$ 7.4) for 2 days, postfixed for $2 \mathrm{~h}$ in potassium ferrocyanide-reduced osmium tetroxide and embedded in epoxy resin (Glysidether 100; M erck, Darmstadt, Germany). Sections (1 $\mu \mathrm{m}$ thick) were cut on a Huxley LKB Ultramicrotome (LKB, Bromma, Sweden) and stained with toluidine blue for light microscopy. Step-serial sections were left unstained for autoradiography. They were coated with Kodak NTB-2 nuclear track emulsion (Eastman Kodak, Rochester, NY, USA) and exposed for 8 days and developed in Kodak D-19 developer. The number of ${ }^{3} \mathrm{H}$-thymidine-labelled cells along the epithelium was counted by light microscopy.

Morphology of epithelium and the epithelial attachment apparatus (EAA)

For electron microscopy, ultra-thin sections from the same tissue explants were cut and stained with uranyl acetate and lead citrate and examined on a JEOL JEM $100 \mathrm{C}$ electron microscope (Japan Electron Optical, Tokyo, Japan). Photographs were taken and further analysed by a computer programme to compare the volume of intercellular spaces in control and in A. actinomycetemcomitans LPS-treated tissue explants - which appeared to be the only ones exhibiting a conspicuous change in this parameter.

\section{Statistical analysis}

The significance of the differences between treatments was tested by an analysis of variance (Statistica computer programme).

\section{Results}

\section{Cell adhesion}

N one of the LTAs or LPSs studied had any direct effect on cell adhesion in either cell line studied (data not shown).

\section{Cell growth}

B oth LTAs studied significantly inhibited $\mathrm{HaCaT}$ cell growth at concentration of $50 \mu \mathrm{g} / \mathrm{ml}$ after culture for 4 days $(p<0.0001$, data not shown). At 7 days, the growth inhibition caused by S. sanguis LTA $(50 \mu \mathrm{g} /$ $\mathrm{ml}$ ) was $28 \%$ (SD $2.5 \%)$ and by S. mutans $(50 \mu \mathrm{g} / \mathrm{ml})$ $97 \%$ (SD 0.2\%), p <0.0001. A. actinomycetemcomitans and $\mathrm{P}$. gingivalis LPS increased $\mathrm{HaCaT}$ cell growth by $8 \%$ (SD 4\%, $p<0.001$ ) and $12 \%$ (SD 5\%, $\mathrm{p}<0.05$ ), respectively (Fig. 1). Neither the LPS from T. denticola nor from E. coli had a significant effect on

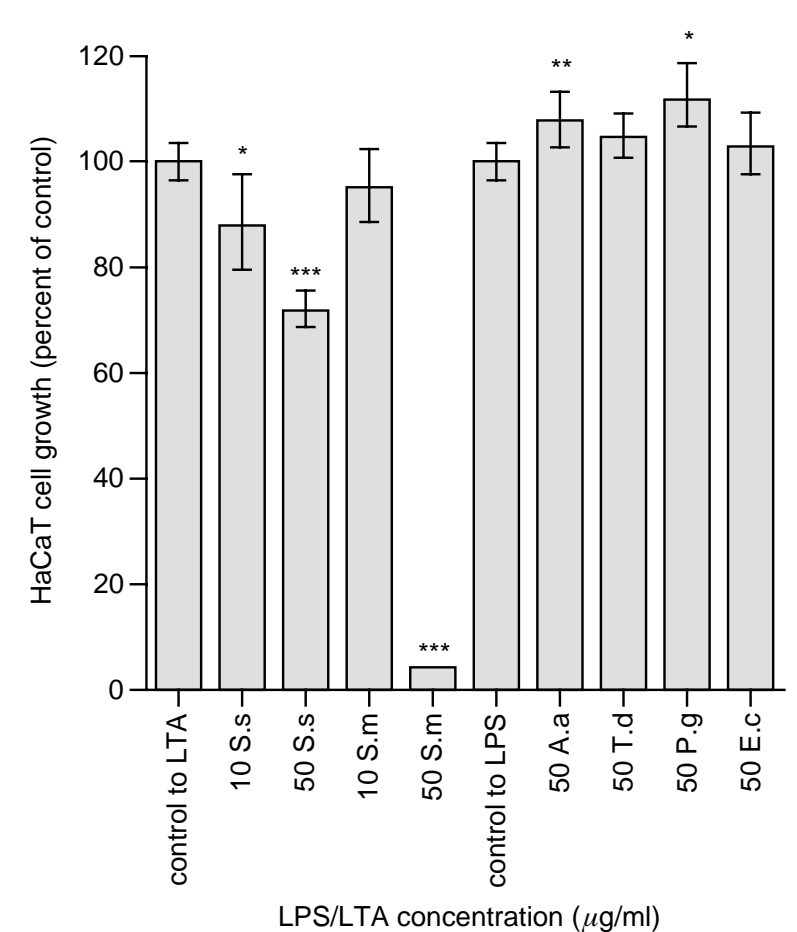

Fig. 1. Effects of LTAs of S. sanguis (S. S) and S. mutans (S. $\mathrm{m})$, and LPSs of A. actinomycetemcomitans (A. a), T. denticola ( $T . d)$, P. gingivalis ( $P . g$ ) and $E$. coli ( $E . C)$ on $\mathrm{HaCaT}$ cell growth (mean and SD of four parallel wells). Cells were grown for 7 days in DMEM + FCS $10 \%$. Cell growth is expressed as percent of control. ***p< $0.0001 ; * * p<0.001 ; * p<0.05$. 
$\mathrm{HaCaT}$ cell growth. In the ERM cell line the effects of the LTAs were essentially similar to those on $\mathrm{HaCaT}$ cells (Fig. 2): S. sanguis LTA $(50 \mu \mathrm{g} / \mathrm{ml})$ reduced ERM cell growth by $42 \%$ (SD 4.8\%, $p<0.0001$ ) and the same concentration of S. mutans LTA by $82 \%$ (SD $1.4 \%, \mathrm{p}<0.0001)$. At $10 \mu \mathrm{g} / \mathrm{ml}$, the LTAs studied did not inhibit ERM cell growth $(p<0.0001)$. The effects of the LPSs on ERM cells were somewhat different to those on $\mathrm{HaCaT}$ cells; $E$. coli LPS had no effect on ERM cells nor on $\mathrm{HaCaT}$ cell growth. A. actinomycetemcomitans, T. denticola and $P$. gingivalis LPSS $(50 \mu \mathrm{g} / \mathrm{ml})$ significantly inhibited ERM cell growth $(p<0.0001, p<0.0001, p<0.001$, respectively). A. actinomycetemcomitans LPS caused a $35 \%$ reduction (SD 4.2\%) in ERM cell growth, T. denticola LPS a $28 \%$ reduction (SD $4 \%$ ) and $P$. gingivalis LPS a $12 \%$ reduction (SD 4.3\%) (Fig. 2).

\section{Proliferation}

In $\mathrm{HaCaT}$ cell cultures a significant inhibition in BrdU intake was observed in cells treated with LTA from both $\mathrm{S}$. sanguis and $\mathrm{S}$. mutans $(\mathrm{p}<0.0001)$ (Table 1$)$. During the BrdU labelling period of $2 \mathrm{~h}, 54 \%$ of the control cells incorporated BrdU label (ratio 1.16), as did $45 \%$ of the LTA - treated cells (ratios $0.86,0.82$ ). When $\mathrm{HaCaT}$ cells were treated with the different LPSs, no significant effects on cell proliferation were observed (Table 1). In ERM cell cultures, both streptococcal LTAS and LPSs from the pathogens

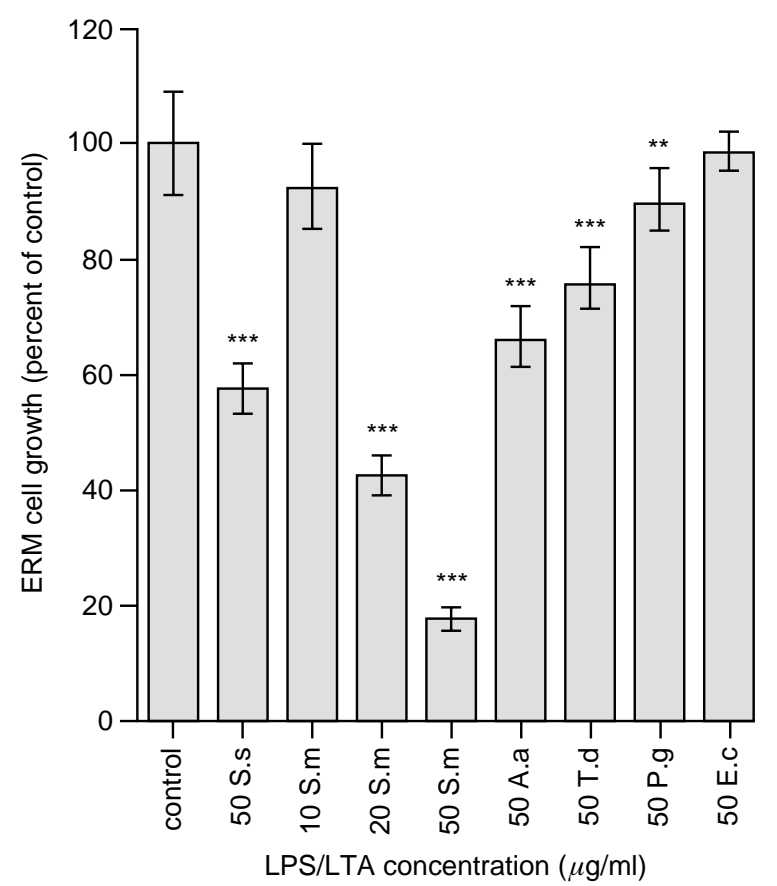

Fig. 2. Effects of LTAS of S. sanguis (S. S) and S. mutans (S. m), and LPSs of A. actinomycetemcomitans (A. a), T. denticola ( $T . d)$, P. gingivalis ( $P . g$ ) and $E$. coli (E. C) on ERM cell growth (mean and SD of four parallel wells). Cells were grown for 7 days in DMEM + FCS 10\%. Cell growth is expressed as percent of control. $* * * p<$ $0.0001 ; * * p<0.001$.
Table 1. BrdU-labelling of $\mathrm{HaCaT}$ cells treated with LTA or LPS $(50 \mu \mathrm{g} / \mathrm{ml})$ for 2 days

\begin{tabular}{lcc}
\hline Treatment & $\begin{array}{c}\text { Average ratio of labelled: } \\
\text { unlabelled cells* }\end{array}$ & SD* \\
\hline Control for LTAs & 1.16 & 0.06 \\
S. sanguis LTA & $0.86^{\dagger}$ & 0.08 \\
S. mutans LTA & $0.82^{\dagger}$ & 0.12 \\
Control for LPSs & 1.17 & 0.17 \\
A. actinomycetemcomitans LPS & 1.14 & 0.23 \\
P. gingivalis LPS & 1.02 & 0.18 \\
T. denticola LPS & 1.07 & 0.09 \\
E. coli LPS & 1.17 & 0.25 \\
\hline
\end{tabular}

*Four parallel fields.

${ }_{\dagger} p<0.0001$.

studied significantly inhibited BrdU-intake $(p<$ $0.0001, p<0.005$, respectively) (Table 2 ). In the untreated primary human explant cultures, the average number of DNA-synthesising epithelial cells inbetween the connective tissue and the filter was 4.26 (SD 2.76) $/ \mathrm{mm}$ of the epithelium (Fig. 3a,b). Treatment of the explants with LTA from $S$. sanguis caused a significant reduction in epithelial cell proliferation $(p<0.05$, Table 3$)$. A reduction in the number of proliferating cells was also observed in cultures treated with S. mutans LTA and P. gingivalis LPS; however, it did not reach statistical significance. Cells treated with A. actinomycetemcomitans, T. denticola or E. coli LPSs did not significantly differ from controls (Table 3 ).

\section{Electron microscopy}

The examination of the JE culture model by electron microscopy showed that in A. actinomycetemcomitans LPS-treated explants, widened intercellular spaces were seen through the whole thickness of the explant epithelium. The intercellular spaces occupied $4.36 \%$ of the epithelial volume in control explants and $14.55 \%$ in A. actinomycetemcomitans LPS-treated explants (Fig. 4a,b,c,d). Explants treated with other LPSs or LTAs had similar morphology to the controls. All explants exhibited normal-looking epithelial cells attached to the substratum with an intact EAA (Fig. $4 b, d, e, f)$. No signs of degenerative vacuolisation observed in DAT cells collected from periodontally involved teeth in vivo [45] were seen (Fig. 4).

Table 2. BrdU-labelling of ERM cells treated with LTA or LPS $(50 \mu \mathrm{g} / \mathrm{ml})$ for 2 days

\begin{tabular}{lcl}
\hline Treatment & $\begin{array}{c}\text { Average ratio of labelled: } \\
\text { unlabelled cells* }\end{array}$ & SD* \\
\hline Control & 0.74 & 0.36 \\
S. sanguis LTA & $0.27^{\dagger}$ & 0.14 \\
S. mutans LTA & $0.03^{\dagger}$ & 0.003 \\
A. actinomycetemcomitans LPS & $0.33^{\star}$ & 0.09 \\
P. gingivalis LPS & $0.30^{\star}$ & 0.19 \\
T. denticola LPS & $0.22^{\star}$ & 0.08 \\
E. coli LPS & $0.36^{\star}$ & 0.05 \\
\hline
\end{tabular}

*Four parallel fields.

${ }^{\dagger} \mathrm{p}<0.0001$.

$t_{p}<0.005$. 


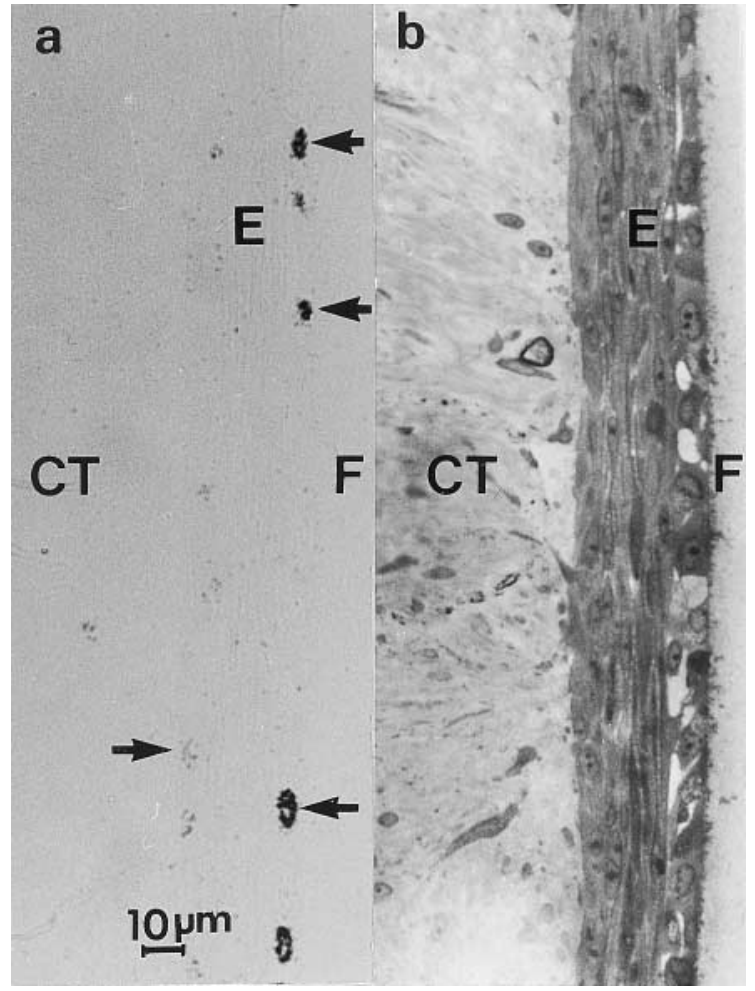

Fig. 3. (a) Photomicrograph of tissue explant labelled with $\left[{ }^{3} \mathrm{H}\right]$ thymidine showing a typical distribution of DNA-synthesising epithelial cells (arrows) both along the connective tissue (CT) and along the filter (F). Section (b) is stained with toluidine blue for tissue localisation. $\mathrm{E}$, epithelium. Bar $=10 \mu \mathrm{m}$ in (a) and (b).

Table 3. $\left[{ }^{3} \mathrm{H}\right]$ thymidine-labelling of human explant model for JE treated with LTA or LPS $(50 \mu \mathrm{g} / \mathrm{ml})$ for 2 days

\begin{tabular}{lcc}
\hline & $\begin{array}{c}\text { Average number of } \\
\text { proliferating cells/mm of } \\
\text { epithelium }\end{array}$ & SD \\
\hline Treatment & 4.26 & 2.76 \\
Control & $1.42^{*}$ & 1.00 \\
S. sanguis LTA & 2.64 & 1.49 \\
S. mutans LTA & 5.54 & 4.93 \\
A. actinomycetemcomitans LPS & 2.14 & 0.76 \\
P. gingivalis LPS & 5.18 & 2.66 \\
T. denticola LPS & 4.80 & 2.47 \\
E. coli LPS & &
\end{tabular}

\section{Discussion}

Gingival JE is a tissue with dividing cells, not only in the basal layer, but also suprabasally along the tooth surface [1,46-48]. Inflammation stimulates the basal cells of JE leading to epithelial sprouting into the connective tissue [49]. However, recently an increasing amount of evidence has suggested that although epithelial cell division is stimulated by inflammation to a certain degree, inhibition and subsequent degeneration and cell death take place when the adaptive threshold is exceeded $[45,50,51]$. In JE, the location of dividing DAT cells away from the connective tissue and blood circulation may (as a result of compromised nutritional conditions, for example) impair their ability to adapt to changes caused by the inflammatory reaction or to external challenges.

B acterial surface antigens, LTAs and LPSs are released by plaque bacteria at a concentration range of $0.4 \mathrm{ng}$ $50 \mu \mathrm{g} / \mathrm{ml}[8,9,12,35]$. The aim of the present work was to examine whether these bacterial agents interfere with the adhesion, attachment, growth and mitotic activity of epithelial cells, thus suggesting a role for these molecules in the degeneration of junctional epithelial cells that is associated with periodontal diseases. For this study, concentrations of $10-50 \mu \mathrm{g} /$ $\mathrm{ml}$ of the LTAs and LPSs were chosen to resemble the concentrations to which the epithelial cells may be exposed in vivo in the sulcular region and that are not yet toxic to cells. A human gingival explant culture model was used to achieve an experimental set up as close as possible to the situation in vivo at the dentogingival junction. Two established epithelial cell lines $[39,40]$ were used because they are well characterised, easy to grow and widely used in other laboratories. Furthermore, an advantage of established cell lines is that the possibility of host-specific variation in response to a given bacterial challenge is eliminated, a possibility to be considered especially regarding the LPSs $[52,53]$.

To study the possible role of LTAs in the initial phase of sulcus formation, streptococcal LTAs from two oral species ( $S$. sanguis and $S$. mutans) were included. The study showed that in all the different cell cultures both of the streptococcal LTAs used at concentrations of $50 \mu \mathrm{g} / \mathrm{ml}$ were potent inhibitors of epithelial cell growth and proliferation. This is a novel finding and suggests that the initial colonisers on the tooth surface are potentially able to affect JE cell proliferation. As even the most coronal DAT cells attached to the tooth surface have been shown to be dividing, the LTAs may have a role in degeneration and subsequent detachment of this population of cells from the tooth surface. Streptococcal LTA production is known to be enhanced in alkaline $\mathrm{pH}$ [54] and elevated $\mathrm{pH}$ values prevail in plaque and in the GCF of gingivitis and periodontitis patients [55, 56]. Therefore, local environmental factors may favour LTA production and thus contribute to epithelial degeneration and exposure of the tooth surface. The formation of a deepened gingival sulcus may either lead to an equilibrium or further contribute to subgingival colonisation by anaerobic pathogens. Clearly, the importance of the immunological defence of the host is emphasised in sites of deepening sulci.

LPSs from parodontopathogens A. actinomycetemcomitans, T. denticola and P. gingivalis were included in the study to examine the possible role of these cellsurface antigens on epithelial pathology and on the progression of periodontal pocket formation. E. coli LPS was included to serve as a reference to the LPSS from periodontal pathogens used in this study and to 

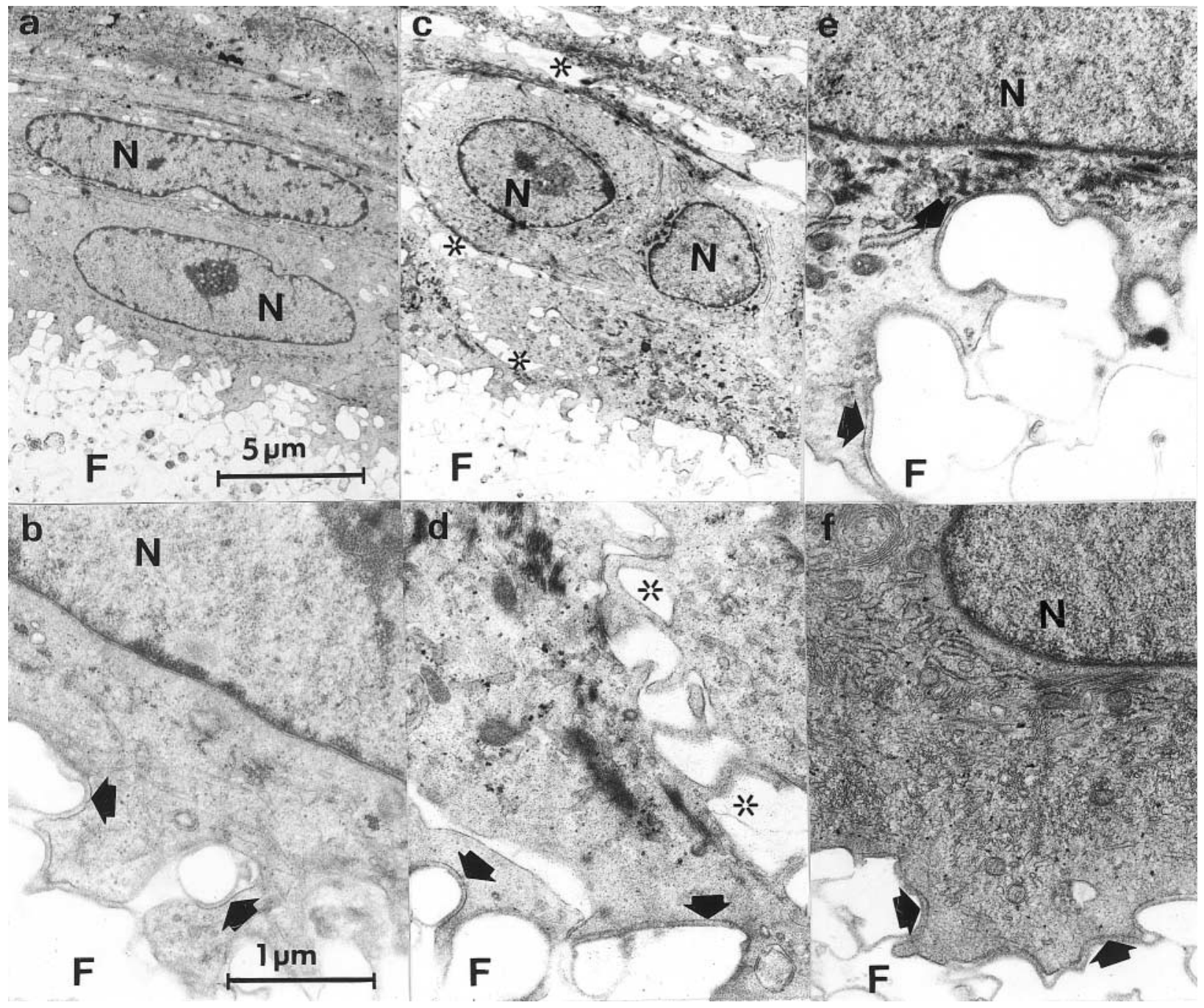

Fig. 4. Electron micrographs showing the epithelial cell-filter interface (arrows). (a) and (b) Control explants, (c) and (d) A. actinomycetemcomitans LPS-treated explants, (e) P. gingivalis LPS-treated explant, (f) S. mutans LTA-treated explant. No obvious differences are seen in the number or structure of hemidesmosomes (HD) of the EAA expressed by the DAT cells of the in-vitro model of junctional epithelium. In A. actinomycetemcomitans LPS-treated explants $(c, d)$, widened intercellular spaces $(*)$ are seen on the whole depth of the explant epithelium. N, nucleus of the cells; $F$, growth filter. Bar $=5 \mu \mathrm{m}$ in (a) and (c); bar $=1 \mu \mathrm{m}$ in (b), (d), (e) and (f).

previous studies that used E. coli LPS. It was found that $50 \mu \mathrm{g} / \mathrm{ml}$ of the LPSs studied had different effects on cell growth and proliferation depending on the type of epithelial cells used. $\mathrm{HaCaT}$ cell growth was slightly increased after treatment with $A$. actinomycetemcomitans and P. gingivalis LPSs for 7 days compared with controls. This increase did not appear to be due to changes in the mitotic activity of the cells. However, it is possible that the mitotic activity of the cells is enhanced after a longer period of exposure than that used in the BrdU assay (2 days) and is, therefore, seen only in the 7-day growth assay. Alternatively, the explanation for the slight increase in cell growth may be due to an increase in cell volume, as the crystal violet staining measures the dye absorbed into cells. Unlike the HaCaT cell cultures, ERM cell growth and proliferation were significantly inhibited by the LPSs of periodontal pathogens. In primary explant cultures the LPSs studied had no effect on the mitotic activity of epithelial cells. In general terms, the observed varying effects of LPSs on cell growth and proliferation are consistent with previous studies, showing growth enhancement or growth inhibition depending on the cell line studied. An inhibition of epithelial cell growth was reported when approximately the same LPS concentration $(6-50 \mu \mathrm{g} / \mathrm{ml})$ as that used in the present study was used [32, 33]. Epithelial stimulation by LPSS has been reported to be significant only at concentrations from $200 \mu \mathrm{g}$ to $5000 \mu \mathrm{g} / \mathrm{ml}[31,34]$.

In conclusion, when compared to the effects of the LTAs shown in this study and to the previously reported effects of the SCFA metabolites of gramnegative anaerobes $[6,7]$ on human epithelial cells, the direct effects of the LPSs shown here seem to be relatively weak - with the exception of A. actinomycetemcomitans LPS, which increased the intercellular spaces of the epithelium. Therefore, it seems that the 
effects of the LPSs are directed mainly towards the inflammatory reaction in the connective tissue rather than the impairment of epithelial cell function. However, it has been shown recently that inflammatory cytokines are hundreds of times more potent in stimulating inflammatory mediator (IL-6) production by fibroblasts than LPSs [57]. The concordance of these sets of results supports the need to critically examine the potency and relative importance of LPSs as pathogenic components in the clinical environment of the JE cells. In contrast, the LTAs of the initial colonisers clearly appear harmful to the vital functions of epithelial cells and thus may influence the balance between the external challenge and host defence at the dentogingival junction.

\section{R eferences}

1. Salonen JI. Proliferative potential of the attached cells of human junctional epithelium. I Periodont Res 1994; 29: 41- 45.

2. Fine $\mathrm{DH}, \mathrm{M}$ andel ID. Indicators of periodontal disease activity: an evaluation. J Clin Periodontol 1986; 13: 533-546.

3. Haffajee AD, Socransky SS. Microbial etiological agents of destructive periodontal diseases. Periodontol 2000 1994; 5: 78-111.

4. Singer RE, Buckner BA. Butyrate and propionate: important components of toxic dental plaque extracts. Infect Immun 1981; 32: 458-463.

5. Botta GA, Radin L, Costa A, Schito G, Blasi G. Gas-liquid chromatography of the gingival fluid as an aid in periodontal diagnosis. J Periodont Res 1985; 20: 450- 457.

6. Pöllänen MT, Overman DO, Salonen JI. Bacterial metabolites sodium butyrate and propionate inhibit epithelial cell growth in vitro. J Periodont Res 1997; 32: 326-334.

7. Sorkin BC, Niederman R. Short chain carboxylic acids decrease human gingival keratinocyte proliferation and increase apoptosis and necrosis. J Clin Periodontol 1998; 25: 311-315.

8. Wicken AJ, Knox KW. Lipoteichoic Acids: A new class of bacterial antigen. Membrane lipoteichoic acids can function as surface antigens of gram-positive bacteria. Science 1975; 187: 1161- 1167.

9. Tzamouranis A, Matthys J, Ishikawa I, Cimasoni G. Increase of endotoxin concentration in gingival washings during experimental gingivitis in man. J Periodontol 1979; 50: 175- 177

10. Millar SJ, Goldstein EG, Levine MJ, Hausmann E. Modulation of bone metabolism by two chemically distinct lipopolysaccharide fractions from Bacteroides gingivalis. Infect Immun 1986; 51: 302-306.

11. Monefeldt K, Tollefsen T. Serum IgG antibodies reactive with lipoteichoic acid in adult patients with periodontitis. J Clin Periodontol 1989; 16: 519-524.

12. Fine $\mathrm{DH}$, Mendieta $C$, Barnett $M L$, Furgang $D, N$ aini $A$, Vincent JW. Endotoxin levels in periodontally healthy and diseased sites: correlation with levels of gram-negative bacteria. I Periodontol 1992; 63: 897-901.

13. Teti G, Tomasello F, Chiofalo MS, Orefici G, Mastroeni P. Adherence of group $B$ streptococci to adult and neonatal epithelial cells mediated by lipoteichoic acid. Infect Immun 1987; 55: 3057-3064.

14. Courtney HS, von Hunolstein C, Dale JB, Bronze MS, Beachey EH, Hasty DL. Lipoteichoic acid and M protein: dual adhesins of group A streptococci. Microb Pathog 1992; 12: $199-208$.

15. Paradis S-E, Dubreuil D, Rioux S, Gottschalk M, Jacques $M$. High-molecular-mass lipopolysaccharides are involved in Actinobacillus pleuropneumoniae adherence to porcine respiratory tract cells. Infect Immun 1994; 62: 3311-3319.

16. Schwartz J, Stinson FL, Parker RB. The passage of tritiated bacterial endotoxin across intact gingival crevicular epithelium. J Periodontol 1972; 43: 270-276.

17. Salzman AL, Wang H, Wollert PS et al. Endotoxin-induced ileal mucosal hyperpermeability in pigs: role of tissue acidosis. Am J Physiol 1994; 266: G633-G646.

18. Snyderman R. Role for endotoxin and complement in periodontal tissue destruction. J Dent Res 1972; 51: 356-361.

19. B ab IA, Sela M N, Ginsburg I, Dishon T. Inflammatory lesions and bone resorption induced in the rat periodontium by lipoteichoic acid of Streptococcus mutans. Inflammation 1979; 3: 345- 358.

20. Hausmann E, Nair BC, Dziak R. Bacterial components which result in bone loss. In: Genco RJ, M erhagen SE (eds) Hostparasite interactions in periodontal diseases. Washington, DC A merican Society of Microbiology. 1982: 151- 159.

21. Lindemann RA, Economou JS, Rothermel H. Production of interleukin-1 and tumor necrosis factor by human peripheral monocytes activated by periodontal bacteria and extracted lipopolysaccharides. J Dent Res 1988; 67: 1131-1135.

22. Bhakdi S, Klonisch T, Nuber P, Fischer W. Stimulation of monokine production by lipoteichoic acids. Infect Immun 1991; 59: $4614-4620$

23. Monefeldt $K$, Tollefsen $T$. Effects of a streptococcal lipoteichoic acid on complement activation in vitro. J Clin Periodontol 1993; 20: 186-192.

24. Loppnow $H, B$ rade $H$, Rietschel ET, Flad H-D. Induction of cytokines in mononuclear and vascular cells by endotoxin and other bacterial products. Methods Enzymol 1994; 236: 3-10.

25. Kamin S, Harvey W, Wilson M, Scutt A. Inhibition of fibroblast proliferation and collagen synthesis by capsular material from Actinobacillus actinomycetemcomitans. J Med Microbiol 1986; 22: 245-249.

26. Larjava H, Uitto V-J, Eerola E, Haapasalo M. Inhibition of gingival fibroblast growth by Bacteroides gingivalis. Infect Immun 1987; 55: 201- 205.

27. Layman DL, Diedrich DL. Growth inhibitory effects of endotoxins from Bacteroides gingivalis and intermedius on human gingival fibroblasts in vitro. J Periodontol 1987; 58: 387-392.

28. Bartold PM, Narayanan AS, Page RC. Platelet-derived growth factor reduces the inhibitory effects of lipopolysaccharide on gingival fibroblast proliferation. I Periodont Res 1992; 27: 499- 505.

29. Hill SJ, Ebersole JL. The effect of lipopolysaccharide on growth factor-induced mitogenesis in human gingival fibroblasts. J Periodontol 1996; 67: 1274-1280.

30. DeRenzis FA, Chen S-Y. Ultrastructural study of cultured human gingival fibroblasts exposed to endotoxin. J Periodontol 1983; 54: 86- 90

31. Uchida K, Samma S, Rinsho K, Warren JR, Oyasu R. Stimulation of epithelial hyperplasia in rat urinary bladder by Escherichia coli cystitis. J U rol 1989; 142: 1122-1126.

32. Zhang B, Wang B, Chen Y, Yang J, Zhang J. Influence of lipopolysaccharide and interleukin-2 on proliferation and synthesis of sulfated macromolecules in cultured rat glomerular epithelial cells. Chin Med J Engl 1996; 109: 609-614.

33. Freitag A, Reimann A, Wessler I, Racke K. Effects of bacterial lipopolysaccharides (LPS) and tumour necrosis factor-alpha (TNF alpha) on rat tracheal epithelial cells in culture: morphology, proliferation and induction of nitric oxide (NO) synthase. Pulm Pharmacol 1996; 9: 149-156.

34. Takata T, M iyauchi M, Ogawa I, Ito H, Kobayashi J, Nikai H Reactive change in proliferative activity of the junctional epithelium after topical application of lipopolysaccharide. J Periodontol 1997; 68: 531-535.

35. Shapiro L, Lodato FM, Courant PR, Stallard RE. Endotoxin determinations in gingival inflammchange in proliferative activity of the junctional epithelium after topical application of lipopolysaccharide. J Periodontol 1997; 68: 531-535.

35. Shapiro L, Lodato FM, Courant PR, Stallard RE. Endotoxin determinations in gingival inflammation. J Periodontol 1972; 43: 591- 596.

36. Rolla G, Oppermann RV, Bowen WH, Ciardi JE, Knox KW. High amounts of lipoteichoic acid in sucrose-induced plaque in vivo. Caries Res 1980; 14: 235-238.

37. Koga $T$, Nishihara T, Fujiwara $T$ et al. Biochemical and immunobiological properties of lipopolysaccharide (LPS) from Bacteroides gingivalis and comparison with LPS from Escherichia coli. Infect Immun 1985; 47: 638-647.

38. Hamada S, Koga T, Nishihara T, Fujiwara T, Okahashi $\mathrm{N}$ Characterization and immunobiologic activities of lipopolysaccharides from periodontal bacteria. Adv Dent Res 1988; 2 284- 291. 
39. Boukamp P, Petrussevska RT, B reitkreuz D, Hornung J, $M$ arkham A, Fusenig NE. Normal keratinization in a spontaneously immortalized aneuploid human keratinocyte cell line. I Cell Biol 1988; 106: 761-771.

40. Brunette DM, Melcher AH, Moe HK. Culture and origin of epithelium-like and fibroblast- like cells from porcine periodontal ligament explants and cell suspensions. Arch Oral Biol 1976; 21: 393-400.

41. Salonen JI, Kautsky M B, Dale BA. Changes in cell phenotype during regeneration of junctional epithelium of human gingiva in vitro. J Periodont Res 1989; 24: 370- 377.

42. Darveau RP, Hancock REW. Procedure for isolation of bacterial lipopolysaccharides from both smooth and rough Pseudomonas aeruginosa and Salmonella typhimurium strains. | Bacteriol 1983; 155: 831-838.

43. Gillies RJ, Didier N, Denton M. Determination of cell number in monolayer cultures. Anal Biochem 1986; 159: 109-113.

44. Kueng W, Silber E, Eppenberger U. Quantification of cells cultured on 96-well plates. Anal Biochem 1989; 182: 16-19.

45. Overman DO, Salonen JI. Characterization of the human junctional epithelial cells directly attached to the tooth (DAT cells) in periodontal disease. J Dent Res 1994; 73: 1818-1823.

46. Salonen JI, Pöllänen MT. Junctional epithelial cells directly attached to the tooth. Schweiz M onatsschr Zahnmed 1997; 107: 137- 140.

47. Schroeder HE. The junctional epithelium: origin, structure and significance. Schweiz Monatsschr Zahnmed 1996; 106: $155-167$.

48. Schroeder HE, Listgarten MA. The gingival tissues: the architecture of periodontal protection. Periodontol 2000 1997; 13: $91-120$
49. Page RC, Schroeder HE. Pathogenesis of inflammatory periodontal disease. A summary of current work. Lab Invest 1976; 34: $235-249$

50. Carro OM, Evans SAS, Leone CW. Effect of inflammation on the proliferation of human gingival epithelial cells in vitro. | Periodontol 1997; 68: 1070-1075.

51. Tonetti MS, Cortellini D, Lang NP. In situ detection of apoptosis at sites of chronic bacterially induced inflammation in human gingiva. Infect Immun 1998; 66: 5190-5195.

52. Garrison SW, Nichols FC. LPS-elicited secretory responses in monocytes: altered release of $\mathrm{PGE}_{2}$ but not $\mathrm{IL}-1 \beta$ in patients with adult periodontitis. J Periodont Res 1989; 24: 88-95.

53. Hernichel-Gorbach E, Kornman KS, Holt SC et al. Host responses in patients with generalized refractory periodontitis. | Periodontol 1994; 65: 8-16.

54. Knox KW, Wicken AJ. Effect of growth conditions on lipoteichoic acid production. In: Schockman GD, Wicken A] (eds) Chemistry and biological activities of bacterial surface amphiphiles. New York, A cademic Press. 1981: 229-237.

55. Bickel M, Cimasoni G. Recent advances in gingival crevicular fluid research. In: Lehner T, Cimasoni G (eds) The borderland between caries and periodontal disease III. Geneva, Editions Medicine et Hygiéne. 1986: 61-70.

56. Sewón L, Söderling E, Karjalainen S. Comparative study on mineralization-related intraoral parameters in periodontitisaffected and periodontitis-free adults. Scand J Dent Res 1990; 98: 305-312.

57. Kent LW, Rahemtulla F, Hockett RD, Gilleland RC, Michalek SM. Effects of lipopolysaccharide and inflammatory cytokines on interleukin- 6 production by healthy human gingival fibroblasts. Infect Immun 1998; 66: 608-614. 